\title{
THE HITTITE LION TOMB, BÜYÜK ASLANTAŞ, IN PHRYGIA*
}

\section{M. Çetin ŞAHIN}

Among the impressive rock-cut monuments in the highlands of Phrygia near Afyon there is one, Büyük Aslantaş, which in all probability is not Phrygian but Hittite ${ }^{1}$ (Pl. I, 1). This tomb, which is $11 \mathrm{~m}$ high, is believed to be one of the earliest monuments in the region. Although the date attributed to the tomb varies ${ }^{2}$, scholars agree that it belongs to the beginnings of the local tradition of carving rock tombs and cult monuments in the highlands of Phrygia. The attribution of the monument to the beginnings of the tradition is justified, since it lacks a pediment, which is common to the Phrygian monuments of the area ${ }^{3}$, and since the relatively small tomb chamber has an almost flat ceiling and not a pitched one.

These two reasons, however, not only justify an earlier date than the other monuments, but also support my belief that the tomb is not Phrygian but Hittite. As mentioned above, the Phrygian monuments have, al-

* This paper was presented at the University of Minnesota in November 1977 and at the 1978 Annual Meeting of the Archaeological Institute of America in Vancouver, Canada (see Abstracts of the AIA, Vol.3, 1978). Cf. Zeitschrift für Papyrologie und Epigraphik 44, 1981, 146, "Aetos: the Greek Pediment".

1. For the monument see W. Ramsay, Journal of Hellenic Studies 9, 1988, $367 \mathrm{ff}$. (and JHS 10, 1889, 147 ff.); G. Perrot-G. Chipiez, History of Art in Phrygia. Lydia, Caria and Lycia, London 1892, 106f.; A. Körte, Athenische Mitteilungen 23, 1898, 134f.; E. Akurgal, Phrygische Kunst, Ankara 1955, 60f. and 90, Die Kunst Anatoliens, Berlin 1961, 86, Ancient Civil. and Ruins of Turkey, Istanbul 1978, pl.81; Goetze, Kleinasien. Abb.34; C.H. Emilie Haspels, The Highlands of Phrygia. Princeton 1971, 118-119, 134-135; P.Z. Spanos, Zeitschrift für Assyriologie 65, 1975, 133-154; F. Işık, Anatolian Siudies 37, 1987, 165-166; F. Prayon, Phrygische Plasrik, Tübingen 1987, 89f.

2. See note 1. Spanos believes that the monument is not a tomb but a cult façade (op.cit., 152f.). This, however, is not acceptable, since one could hardly find another explanation for the presence of a chamber on the monument (see also n.20).

3. For other monuments of the highlands see esp. Haspels, op.cit. The Phrygian monuments seem to have either both a pediment on their façades and a pitched ceiling in the tomb chamber, or rarely only one of these (see, for instance, $\mathrm{Ha}$ mam Kaya - Haspels, op.cif., 113f.-, which lacks a pediment but has a pitched ceiling). 
most exclusively ${ }^{4}$, a pediment on their façades and a pitched ceiling in the tomb chamber. Moreover, if this monument were Phrygian, one would expect that it too would scarcely have lacked at least one of these features. Besides, the monument lacks geometric ornaments on its façade, which is typical of the Phrygian monuments of the area, and it bears no Phrygian inscriptions.

Another reason which suggests a Hittite origin is that there are two monumental lions represented on the façade of the monument, which are believed by all scholars to be in Hittite traditions.

The most important evidence suggesting a Hittite origin for the tomb is the relief decoration crowning the façade (pl.I, 1). Unfortunately the reliefs on the façade are greatly weathered, so that the details are not very clear. A T-shaped relief, however, with the bottom of the $\mathrm{T}$ resting on the door of the tomb chamber and its two arms crowning the façade, may clearly be seen. The crowning member of this T-shaped decoration has formerly been designated as a cornice ${ }^{6}$. Some scholars believe that this "cornice", together with the vertical member below, commonly designated as a column or obelisk?, has no architectural meaning and that it was to be removed ${ }^{8}$ (evidently because this so-called cornice is unique among the rock monuments of Anatolia). C.H. Emilie Haspels, for instance, writes as follows: "On the façade the T-shaped area between and above the lions shows the remains of the original surface. Possibly it had been the intention to remove it in the end. But the crossbar serves for protection against rain water, and the vertical bar does not take away from the general effect; it is hardly noticed" ". If this monument, however, were indeed Phrygian, which I do not believe, it could not have been the intention to remove the $T$-shaped relief in the end, since we know from unfinished Phrygian rock-cut monuments, that the Phrygians began to carve the monument from the top of the rock, and that they first finished its upper part ${ }^{10}$. Hence, there is no reason to doubt that the monument was finished, and that the T-shaped relief on the façade had, whether architectural or not, a definite meaning ${ }^{11}$.

4. See n.3. Akurgal states that Delikli Taş, too, lacks a pediment (Phrygische Kunst, 90). However, it does have a pediment on its very top (see, for instance, Haspels, op.cit., Figs. 209-213).

5. See esp. Akurgal, Phrygische Kunst, 60f., and Die Kunst, 86. If the monument were indeed Phrygian and not Hittite, it would be very difficult to explain the presence of lions, i.e. the sacred animals of Cybele, on a sepulchral monument (cf. Spanos, op.cit., 153).

6. Haspels designates it as a "crossbar" (op.cir., 119).

7. Haspels (ihid.) "vertical bar"; for other designations see Spanos, op.cit., 144f.

8. Haspels, op.cit., 119; Körte, op.cit., 135.

9. Haspels, op.cit., 119.

10. Haspels, op.cit., 77f., esp.79 (Unfinished Monument).

11. The "crossbar" was most probably not left there to protect the relief from rain water. 
What, then, is the meaning of this crowning "cornice" at the top? The only explanation for this unique crowning member, which suggests itself, is that it represents the wings of a winged solar disc. That this member represents wings, is further suggested by its flexible nature and its wavy outline. If it were an architectural member such as a cornice, for instance, it would have had a much more regular outline and most probably no curves at the ends. Why both of these wings are not exactly symmetrical may perhaps be explained by the natural outline of the rock at the top; although the top of the rock, like the sides, has been smoothed ${ }^{12}$, it seems that the upper left part of the rock was left as it was. It seems, therefore, that the wing on the left side follows the original wavy outline of the top of the rock. In any case, it is insignificant whether or not the upper left-hand part of the rock was originally wavy, and even the fact that the two arms of this "cornice" are not exactly symmetrical, would support my thesis that they can only represent flexible objects such as wings. What else could this "cornice" possibly represent, if not wings?

We may therefore conclude that the crowning member on the façade of the monument above the lions represents the wings of a winged solar disc. If this be true, then there is no doubt that the monument is not Phrygian but Hittite. What is the function of a Hittite winged solar disc on this tomb? In Egypt the royal winged solar disc crowned, besides objects such as royal furniture ${ }^{13}$, also temple pylons, shrines, funerary stelae, the doors of royal tombs, and most probably also the gates of palaces ${ }^{14}$. The Hittite winged solar disc crowned, so far as we know, (Pl.I, 3), chiefly deities and/or deified kings and the aedicula in which the names of Hittite kings were written. I believe, however, that it served also a similar purpose as in Egypt, i.e. crowning royal buildings, since we already know a Hittite monument, the so-called shrine at Eflatun Pinar, which is crowned by a winged solar disc ${ }^{15}$. Hence, the presence of a winged solar disc on the monumental rock-tomb Büyük Aslantaş, which, in any case, must have been a royal tomb, should not at all surprise us.

The pillar-like relief below, between the lions has become greatly weathered, thus it is not possible to draw any definite conclusions as to the meaning of this relief. It may represent either the pillar of heaven or any of the pillar-like Hittite hieroglyphic signs ${ }^{16}$.

12. Haspels, op.cit., $118 \mathrm{f}$.

13. See, for instance, the chairs of King Tutanchamun.

14. The word (royal) tomb in Egyptian is also to be interpreted as "palace". Since the winged solar disc, a royal emblem, crowned the door of royal tombs, one may assume that it also crowned the gates of palaces.

15. For the connection of the Egyptian winged solar disc with the Greek pediment see M.Ç. Sahin, "Aetos; the Greek Pediment", Zeitschrift für Papyrologie und Epigraphik 44, 1981, 146. For the so-called shrine at Eflatunpınar see, for instance, Akurgal, The Art of the Hittiter, 106f. and PI.XXI; Bossert, Altanatolien, nos. 526-527; Mellaar, Anat.St. 11, 1961, III-7.

16. According to Akurgal it is a phallus (Phrygische Kunst, 90). See, however, Spanos, op.cit., $144 \mathrm{f}$. 
Having concluded that the Lion Tomb Büyük Aslantaş is a Hittite royal tomb, I should now like to discuss the question of whether or not the Hittites had a tradition of rock-tombs. It seems that the Hittites indeed had such a tradition, since we find the evidence of this already in Yazıllkaya, the well-known open air sanctuary of the Hittites near their capital Haftusas; in Gallery B there are some niches in the rock, which may have served the purpose of receiving the bones and ashes of the deceased and deified kings ${ }^{17}$. Other niches (cavities) are known in the necropolis at Osmankaya near Yazıl1kaya ${ }^{18}$. Moreover, we learn from literary sources that the Hittites, after cremation, deposited the bones of the dead in the "Stone-House"19. This, too, the designation of the tomb as a "StoneHouse", may be taken as a strong indication that the Hittites did have a tradition of rock-tombs ${ }^{20}$.

Because of its striking resemblance to the Lion Gate at Mycenae (see below), Büyük Aslantaş in all probability belongs to a period before the destruction of the Hittite Empire in c. 1200 B.C. Hence, another question poses itself: whether there is any evidence for a Hittite occupation in the highlands of Phrygia before c.1200 B.C. Although the Hittites may have simply carved this monument here, far irom their main territory in the Halys basin and the surrounding area, for the same unknown reason that they carved monuments as far west as Magnesia ad Sipylum near the Aegean $\mathrm{Sea}^{21}$, there seems indeed to be some evidence for a Hittite occupation in the highlands of Phrygia before the arrival of the Phrygians. First of all, pottery belonging to the second millennium B.C., whether Hittite or not (see below), is present in the territory ${ }^{22}$. Secondly, a Hittite hieroglyphic inscription dating from the Empire period, now lost, was found by Ramsay at Beyköy Hüyük near Afyon, located within two miles of the Lion Tomb Büyük Aslantaş ${ }^{23}$. Although the stone may indeed have been brought here from elsewhere, I do not believe that it was brought from very far, contrary to the opinion of Haspels ${ }^{24}$, since the stone was found by Ramsay in 1884 , which means that the large stone would have had to be brought here without the aid of a motor vehicle. We may therefore

17. See, for instance, Akurgal, The Art of the Hittites, $103 \mathrm{ff} ., 106$.

18. Ihid., 103 f.

19. Ihid., 105f.

20. One may suggest that the tomb chamber of Büyük Aslantas is too small for a Phrygian burial. However, if we accept that the monument is not Phrygian but Hittite, then there would be ample room in the tomb chamber for a funerary urn that contained the bones and ashes of the deceased.

21. For these monuments see, for instance, Bossert, op.cit., nos.553-562; Akurgal, The Art of the Hittites, Pls. XX-XXIV.

22. Haspels, op.cit., 288; for a survey in the area see H. Gonnet, Anat.St. 31, 1981, 181-183.

23. Ramsay, Ath.Mitt. 14, 1889, 181, fig.3; Haspels, op.cit., 63 and 288; for a recent study of the inscription see E. Masson, Kadmos XIX, 1980, 118-120.

24. Haspels, op.cit., 288. 
conclude that the stone originates from somewhere in the highlands, even from Beyköy Hüyük itself, or from the immediate vicinity. The third point of evidence consists of the large relief figures carved on the rock flanking the sloping road which leads up to the city of Midas ${ }^{25}$. These reliefs cannot be dated with certainty, and it is doubtful whether they are Phrygian. In any case, the praying posture of some of the figures is clearly in Hittite tradition, and Akurgal suggests that they are indeed Hittite and not Phrygian'2. It is also believed that the symbols on one of the reliefs are Hittite hieroglyphic signs, but this too is disputed. It is insignificant, however, whether or not the highlands of Phrygia were occupied by the Hittites during the second millennium B.C. They were occupied by some people, and these people may very well have formed a vassal state controlled by the Hittites. It is even possible that a Hittite prince governed this state. Consequently, the monumental tomb under discussion, which, in all probability, is Hittite and belongs to the period before c. 1200 B.C., may have been made for one of these vassal kings, who may or may not have been Hittite himself ${ }^{27}$.

The striking resemblance of the Lion Tomb, Büyük Aslantaş, in Phrygia to the Lion Gate at Mycenae, which is dated to c.1250 B.C., is another piece of evidence which supports my thesis that Büyük Aslantaş is Hittite and dates from before c.1200 B.C., and not from the end of the eighth century B.C. or from the first half of the sixth century B.C. (see Pl.I, 2). That Büyük Aslantaş in Phrygia and the Lion Gate at Mycenae are related to each other has already been emphasized by scholars who in the past had discussed Büyük Aslantaş in some detail ${ }^{28}$. Although there are some differences between these two monuments, such as the absence of the two reclining lion cubs at the Lion Gate at Mycenae and the frontal heads of the lions of the same monument ${ }^{29}$, the composition -not the style- is almost identical: a column flanked by two monumental lions standing on their hind legs with their forepaws resting on the base (at the same time the door of the tomb chamber) of the column. In both instances the composition is monumental. That on both monuments the lions are fe-

25. See Haspels, op.cit., 83-84, Figs.19-24; Akurgal, Phrygische Kunst., 66, and Anadolu (Anatolia) III, 1958, 147-155; cf. also F. Prayon, Phrygische Plastik. $87 \mathrm{f}$.

26. Akurgal, op.cit., loc.cit. Although Akurgal suggests in his Phrygische Kunst that the reliefs may belong to the Hittite Empire period, he changes his opinion in the cited article and dates the reliefs to the late Hittite period. Whether or not there was a late Hittite occupation in this territory, is, however, not yet clear.

27. On the lower right-hand side of the façade of the tomb there is a horizontal row of holes on the rock, which most probabiy served for receiving the ends of the beams supporting the roof of a structure for an unknown purpose. I am tempted to believe that there was a chapel here for worship of the deceased person.

28. Ramsay, JHS 9, 1888, 369f.; Körte, AM 23, 1898, $134 f$.

29. For the differences between the two monuments see Ramsay, ibid.; Körte, ibid. 
male is further evidence which links them together. That in the case of the Lion Gate at Mycenae both of the hind legs of the lions have been rendered, in contrast to only one back foot on the Lion Tomb in Phrygia, is insignificant, since this is only a stylistic difference.

On the basis of the striking resemblance of the two monuments under discussion, Ramsay went even so far as to date the Mycenaean Lion Gate to the eighth century B.C., stating that it was influenced by the Lion Tomb in Phrygia ${ }^{30}$. Körte also maintains that, despite the differences, the relation between the two monuments cannot be denied ${ }^{31}$. Hence, if we accept that the Lion Tomb in Phrygia is not Phrygian but Hittite, and that it belongs to a period before 1200 B.C., then its relation to the Lion Gate at Mycenae also becomes clear.

The question whether the Lion Gate at Mycenae influenced the Lion Tomb in Phrygia or vice versa, cannot yet be answered with certainty. It seems very probable that the Lion Gate at Mycenae is older and served as the model, because it crowned a monumental gate at Mycenae, the Achaean capital. The fact, however, that monumental sculpture of these proportions, common in Hittite art, was very uncommon in Mycenaean art, speaks against such an assumption. This problem may be solved in the future, if the Lion Tomb in Phrygia, perhaps through excavations in front of the monument ${ }^{32}$, can be dated with some accuracy. In any case, it seems clear that the two monuments under discussion are related to each other, and that they both belong to a period before $1200 \mathrm{~B}$.C. This conclusion should suffice for the present time.

30. Ramsay, op.cit., 370.

31. Körte, op.cit., 134.

32. See n.27. 

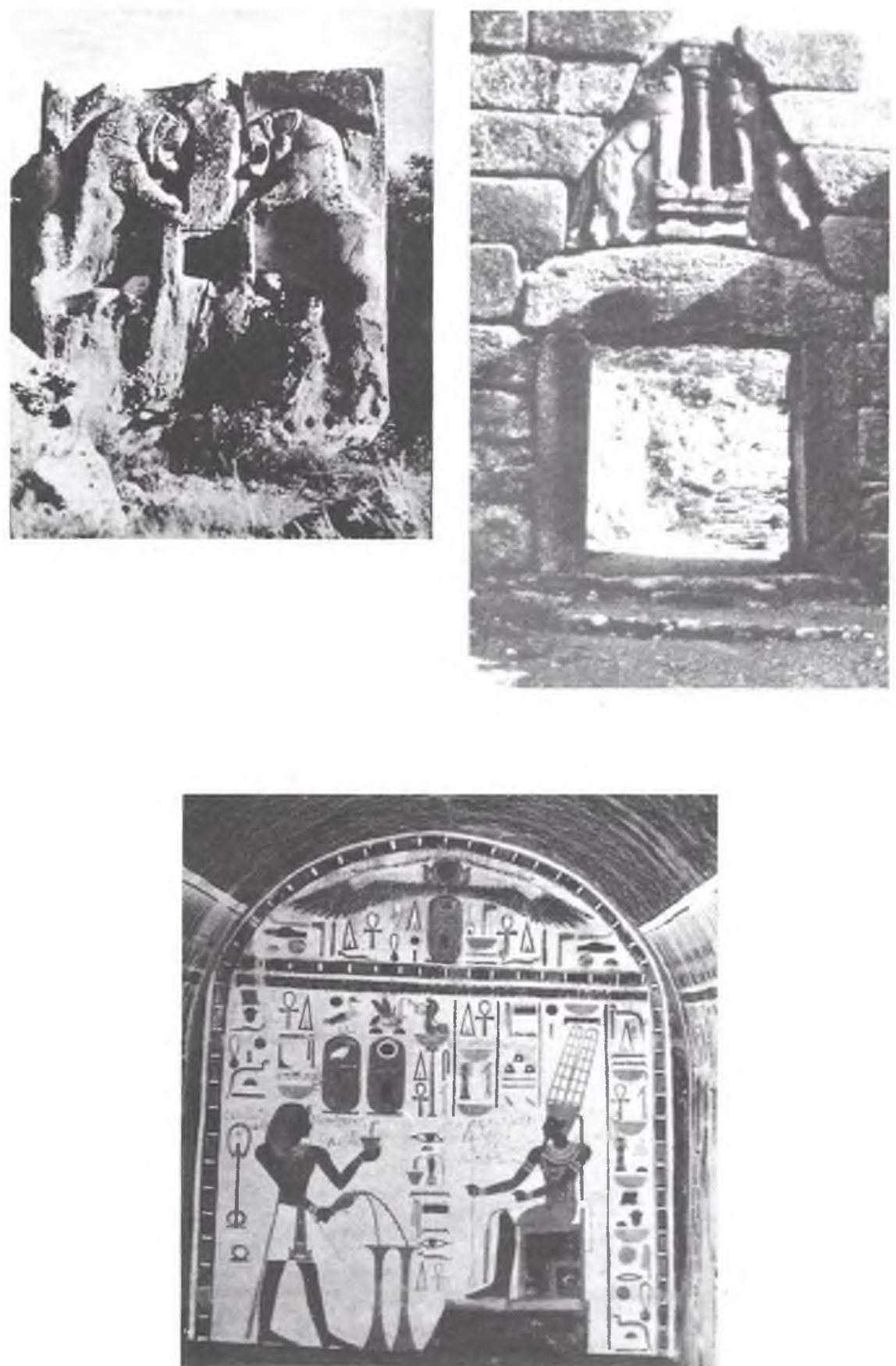